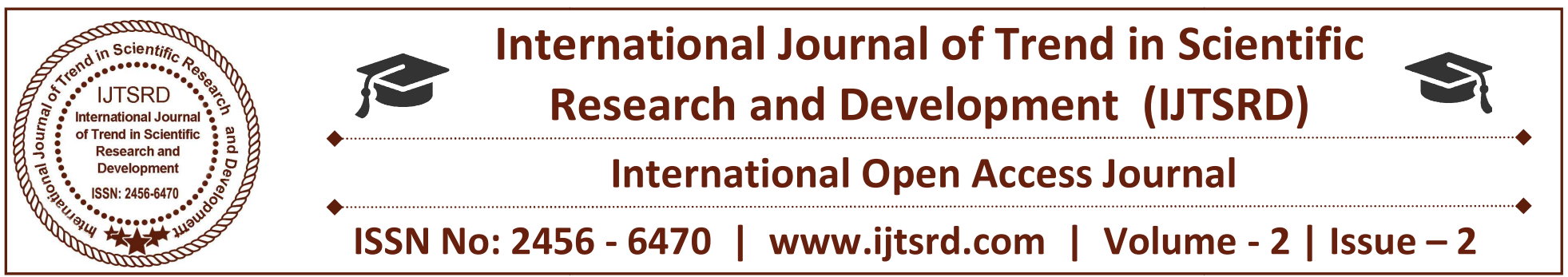

\title{
Green Marketing: Barriers and Suggestions
}

\author{
Nisha Yadav \\ Assistant Professor, Department of Commerce and Management, \\ Indira Gandhi University, Meerpur, Rewari, Haryana, India
}

\begin{abstract}
\end{abstract}
Environmental issue is an emerging trend now a day as almost every country's government and society has started to be more aware about these issues. This leads to a trend of green marketing used by the firms as one of the strategies in order to gain profit and protect the environment. The term Green Marketing came into prominence in the late 1980s and early 1990s. The last decade has shown that harnessing consumer power to effect positive environmental changes is far easier said than done. Consumers and manufactures have been shifted their focus on ecological goods that are presumed to be green or can say that are environmental friendly. It encourages the innovation in existing products and introduction of new products. Consumers are active supporters of environmental health and are the heaviest purchasers of green and socially responsible products. They also have the power to influence other consumers. The green movement has been expanding rapidly in the world. With regards to this consumers are taking responsibility and doing the right things. Consumer awareness and motivation continue to drive change in the marketplace, notably through the introduction of more ecofriendly products. Social movements, media are also nowadays enhancing consumer's attention towards the environmental effects a product may have. To cope with these changes in the society, marketers have adopted green marketing concept in order to sustain in the market. The purpose of this study is to investigate the impact of Green Marketing on Consumer Buying Patterns and Decision Making.

Keywords: Consumers, Green Marketing, Buying Pattern, Ecofriendly, Environment

\section{OBJECTIVES OF THE STUDY}

The main objectives of research paper are as follows:-

- To investigate the impact of green marketing on consumer buying behavior.

- To know the concept of green marketing.

- To find out the solutions of green marketing barriers.

\section{RESERCH METHODLOGY}

The research is exploratory in nature; it focuses on Literature review, News Papers, Journals, websites and the other reliable sources.

\section{INTRODUCTION}

The green movement has been expanding rapidly in the world. With regards to this consumers are taking responsibility and doing the right things. Consumer awareness and motivation continue to drive change in the marketplace notably through the introduction of more eco-friendly products. Compared to consumers in the developed countries, the Indian consumer has much less awareness of global warming issues.

According to the American Marketing Association, green marketing is the marketing of products that are presumed to be environmentally safe. Thus green marketing incorporates a broad range of activities, including product modification, changes to the production process, packaging changes, as well as modifying advertising. 
Pride and Ferrell (1993) Green marketing, also alternatively known as environmental marketing and sustainable marketing, refers to an organization's efforts at designing, promoting, pricing and distributing products that will not harm the environment.

Polonsky (1994) defines green marketing as .all activities designed to generate and facilitate any exchanges intended to satisfy human needs or wants, such that the satisfaction of these needs and wants occurs, with minimal detrimental impact on the natural environment.

Elkington (1994: 93) defines green consumer as one who avoids products that are likely to endanger the health of the consumer or others; cause significant damage to the environment during manufacture, use or disposal; consume a disproportionate amount of energy; cause unnecessary waste; use materials derived from threatened species or environments; involve unnecessary use of, or cruelty to animals; adversely affect other countries.

Green, environmental and eco-marketing are part of the new marketing approaches which do not just refocus, adjust or enhance existing marketing thinking and practice, but seek to challenge those approaches and provide a substantially different perspective. In more detail green, environmental and eco-marketing belong to the group of approaches which seek to address the lack of fit between marketing as it is currently practiced and the ecological and social realities of the wider marketing environment. Belz F., Peattie K.(2009): Sustainability Marketing: A Global Perspective. John Wiley \& Sons.

The most recent definition of green marketing has completely progressed in terms of its variables. It states that green marketing involves the marketing strategies used to achieve a firm's financial as well as strategic goals while reducing its negative impact on the environment. (Leonidou et al., 2013).

\section{HISTORY OF GREEN MARKETING}

\section{According to Wikipedia}

The term Green Marketing came into prominence in the late 1980s and early 1990s. The proceedings of this workshop resulted in one of the first books on green marketing entitled "Ecological Marketing".
The Corporate Social Responsibility (CSR) Reports started with the ice cream seller Ben \& Jerry's where the financial report was supplemented by a greater view on the company's environmental impact. In 1987 a document prepared by the World Commission on Environment and Development defined sustainable development as meeting "the needs of the present without compromising the ability of future generations to meet their own need", this became known as the Brundtland Report and was another step towards widespread thinking on sustainability in everyday activity. Two tangible milestones for wave 1 of green marketing came in the form of published books, both of which were called Green Marketing. They were by Ken Peattie (1992) in the United Kingdom and by Jacquelyn Ottman (1993) in the United States of America.

According to Jacquelyn Ottman, (author of "The New Rules of Green Marketing: Strategies, Tools, and Inspiration for Sustainable Branding" (Greenleaf Publishing and Berrett-Koehler Publishers, February 2011)) from an organizational standpoint, environmental considerations should be integrated into all aspects of marketing - new product development and communications and all points in between. The holistic nature of green also suggests that besides suppliers and retailers new stakeholders be enlisted, including educators, members of the community, regulators, and NGOs. Environmental issues should be balanced with primary customer needs.

The past decade has shown that harnessing consumer power to effect positive environmental change is far easier said than done. The so-called "green consumer" movements in the U.S. and other countries have struggled to reach critical mass and to remain in the forefront of shoppers' minds.

Despite these challenges, green marketing has continued to gain adherents, particularly in light of growing global concern about climate change. This concern has led more companies to advertise their commitment to reduce their climate impacts, and the effect this is having on their products and services. 
GREEN PRODUCTS \& ITS CHRACTERSTICS

The products those are manufactured through green technology and that caused no environmental hazards are called green products. Promotion of green technology and green products is necessary for conservation of natural resources and sustainable development. We can define green products by following measures:

- Products those are originally grown,

- Products those are recyclable, reusable and biodegradable,

- Products with natural ingredients,

- Products containing recycled contents, non-toxic chemical,

- Products contents under approved chemical,

- Products that do not harm or pollute the environment,

- Products that will not be tested on animals,

- Products that have eco-friendly packaging i.e. reusable, refillable containers etc

\section{GREEN CONSUMER}

In order to understand the concept of green marketing, it is necessary to understand a green -consumer. Elkington (1994) defines a green consumer as an individual who indulges in avoiding the use of products that endanger the environment due to their manufacturing or disposing methods, or products that involve animal cruelty or products that are obtained from threatened species. Numerous green marketing research papers, which are based on consumer behavior, include factors that impact green purchase, different consumer segments in green marketing, consumer's decision based on their willingness to pay and consumer profiling (Peattie, 2001). In line with the same, in a study conducted by Laroche (2001), it was identified that most green consumers are very likely to be educated young 7 adults, who spend money on both green and non-green products in anticipation that they work just as efficiently and effectively (Laroche et al., 2001). From the findings of another recent study, it was observed that the knowledge consumers have about environmentally friendly products is one of the contributing factors that influence their decisions to purchase green products (Khare et al., 2013). These studies show that different consumers have different approaches and drivers for green purchase. Ottman (1993) and Peattie (2001), classify green consumer needs in four categories including having knowledge and information, preserving their choice of lifestyle, desires to be substantive and the desire to control.

\section{GOLDEN RULES OF GREEN MARKETING}

There are some golden rules of green marketing. These are discussed in detail are as follows:-

\section{Know you're Customer}

Make sure that the consumer is aware of and concerned about the issues that your product attempts to address, (Whirlpool learned the hard way that consumers wouldn't pay a premium for a CFC-free refrigerator because consumers dint know what CFCs were.).

\section{Educating your customers}

It isn't just a matter of letting people know you're doing whatever you're doing to protect the environment, but also a matter of letting them know why it matters. Otherwise, for a significant portion of your target market, it's a case of "So what?" and your green marketing campaign goes nowhere.

\section{Being Genuine \& Transparent}

It means that a) you are actually doing what you claim to be doing in your green marketing campaign and b) the rest of your business policies are consistent with whatever you are doing that's environmentally friendly. Both these conditions have to be met for your business to establish the kind of environmental credentials that will allow a green marketing campaign to succeed.

\section{Reassure the Buyer}

Consumers must be made to believe that the product performs the job it's supposed to do-they won't forego product quality in the name of the environment.

\section{Consider Your Pricing}

If you're charging a premium for your product-and many environmentally preferable products cost more due to economies of scale and use of higher-quality ingredients-make sure those consumers can afford the premium and feel it's worth it.

\section{Giving your customers an opportunity to participate}


It means personalizing the benefits of your environmentally friendly actions, normally through letting the customer take part in positive environmental action.

\section{Thus leading brands should recognize that consumer expectations have changed}

It is not enough for a company to green its products; consumers expect the products that they purchase pocket friendly and also to help reduce the environmental impact in their own lives too.

\section{CONSUMER BUYING BEHAVIOR TOWARDS GREEN PRODUCTS}

McKinsey Quarterly, Mar 2008 report based on the survey conducted in Brazil, Canada, France, Germany, India, United Kingdom and the United States has revealed that, consumers say that they are concerned about the environment and worried about the air pollution, depletion of natural resources, hole in the ozone layers, shrinking of animal habitat etc. Further to this, the report has indicated that, $87 \%$ of these consumers are concerned about the environmental and social impacts of the products they buy. However, when it comes to actual purchase, the purchase behavior differs from what they say. It may be because of consumer's laziness, not sincere towards environment. But, it may not be the only reason for not buying the green product. It may be consumers are not properly educated about the benefit of green products or it may be firms are not been able to make the green products which can satisfy consumers by fulfilling their needs. Many customers buy Green Product for non-green reason without even Knowing that they are green or not necessarily for environmental reasons while buying the product. For example, recycle or biodegradable paper products like napkins, towels, computer paper etc

\section{BARRIERS OF GREEN BUYING BEHAVIOUR}

Some barriers regarding green buying behavior are as follows-

- Lack of Awareness:-Many researchers have established the fact that, consumers are aware that reducing greenhouse will have a positive effect on environment and moreover consumers want to save the environment. However, they are confused and do not understand how to act upon it. Companies need to educate the consumers regarding the environment, and produce green products such that the product mix will satisfy the consumers.

- Negative Perceptions:-Many green products suffer the issue of reputation. According to GfK Roper Green Gauge study, 2007, Consumers believe that green products are low in performance, high in price and less features. Negative perception can be removed only by making good green product.

- Distrust:-According to GfK Roper Survey, Consumers today doubt the quality associated with a green product. Even they doubt whether products claimed as green are actually green product or not. In order to remove the barrier Distrust from the minds of consumers, the firms should be very honest to their consumers.

- High Prices:-UK Department for Environment, Food and Rural Affairs in its survey conducted in 2007 found that, Price is the largest barrier to Green Marketing. It was found that from the survey that, consumers perceive the benefit green goods is small as compared to the premium they pay for it as compared to the conventional products. Consumers also likely find it difficult to ascertain the environmental performance or Green claims of a product.

Low Availability:-Sometimes it may happen that, consumers want Green Product but not easily available. For example, Biofuel -it is not easily available. Similarly, we can bring another example like clean energy. It may not be possible to consume clean energy because the local infrastructures do not support that.

\section{STEPS TO REMOVE THE BARRIERS}

Knowing what stops consumers from buying green products is only half the work done.

The other half of the work is to know how to break down these barriers. Five steps have been suggested to break down the barriers (Sheila Bonini and Jeremy Oppenheim, Fall 2008). The steps are mentioned as under:

- Educate Consumers:- Firms need to educate their customer regarding the Green Product because largely consumers are not aware of Green products, its benefits and it availability as compared to conventional products. To cite an 
example, Proctor \& Gamble has been sharing the information with consumers about ways to save consumption of water, save energy etc. through its brands includes Tide, Pampers and Duracell.

- Build Better Products:-In order to remove the perception that, Green Products are not having better performance than the conventional products, firms need to manufacture better than conventional alternatives as consumers still prefer reliability, durability, performance etc. than environmental friendly. Therefore, if the green products perform better than the conventional products, consumers will prefer green products because of double benefits. To cite an example, Toyota had a perception that the Prius had less power than non-hybrid cars. In order to overcome the same, Toyota re-designed the Prius to meet performance and style preference of consumers and promoted the vehicle as "quick, roomy and economical.',

- Be Honest:-Companies must be honest while claiming that and they should inform the public about the true impact on environment. The claims should be able to be substantiated. Otherwise consumers will not believe the green claims given by companies.

- Offer more:-It is essential for the firms to ensure that consumer should get the return of their investment by getting both financial and environmental benefits. Consumers will be ready to purchase provided they get convinced that, their product gives the conventional benefits as well as it helps to save the environment.

- Bring products to the People:-Generally consumers find difficult to get the green products. In order to avoid the difficulties, firms should bring products to the people and effective communication to be made. According to Auto Insight, Toyota has increased production of the Prius by an average of 50\% a year since 1999 with its intention to make the prius widely available by running the advertisement which says "We have significantly increased production on the hard-tofind, easy-to-drive Toyota prius"

\section{CONCLUSION}

Green Marketing is rising in its popularity and becoming a widespread research area. Green Marketing had been prevalently researched in developed countries for decades but is only drawing interest from developing nations in the recent past. Therefore, green marketing is a tool now used by many companies to increase their competitive advantage as people is presently very concerned about environmental issues. In the time apply in green marketing; the companies have to comply with the consumers' needs and wants. Consumers want to recognize themselves with companies that are green compliant and are willing to pay more for a greener life style. For this reason, green marketing is not only an environmental protection tool but also a marketing strategy. This is to give them knowledge on how to promote the green product effectively by clearly presenting the main message to the consumers.

\section{REFERENCES}

1. Aditi jaju (August 2016),"A study of the Impact of Green Marketing on Consumer Purchasing Patterns and Decision Making"

2. Ameet Sao (May 2014), "A Research paper on green marketing" IOSR Journal of Business and Management.

3. Belz F., Peattie K. (2009) "Sustainability Marketing: A Global Perspective" John Wiley \& Sons.

4. Jacquelyn Ottman (2010) "The New Rules of Green Marketing: Strategies, Tools, and Inspiration for Sustainable Branding".

5. Polonsky, M., Ottman, J. (1998a), "Exploratory examination of whether marketers include stakeholders in the green new product development process", Journal of Cleaner Production.

6. Pride and Ferrell, "marketing", 2010 edition.

7. http://www.google.com

8. http://www.greenmarketing.net/strategic

9. http://www.businessworld.in

10. http://www.outlookindia.com

11. http://en.wikipedia.org

12. http://www.business-standard.com

13. http://www.encyclopedia.com 